\title{
Histopathologic Changes in the Kidney Tissue of Prochilodus lineatus Valenciennes, 1836 (Characiformes, Prochilodontidae) Induced by Sublethal Concentration of Trichlorfon Exposure
}

\author{
Marcelo Leite da Veiga ${ }^{1 *}$; Edson de Lara Rodrigues ${ }^{1}$; Fabio Juliano Pacheco ${ }^{1}$ and Maria \\ José Tavares Ranzani-Paiva ${ }^{2}$ \\ ${ }^{1}$ Laboratório de Impacto Ambiental e Histopatologia; Centro Universitário Adventista de São Paulo; Estrada de \\ Itapecerica da Serra, 5859; CEP 05858-001; São Paulo - Brazil. ${ }^{2}$ Instituto de Pesca; Secretaria da Agricultura e \\ Abastecimento; Av. Francisco Matarazzo, 455; CEP 05001-900; São Paulo - SP - Brazil
}

\begin{abstract}
Studies were carried out to analyse the kidney histopathological alterations of "curimbatá", Prochilodus lineatus, were analyzed. An acute bioassay was made by the water contamination with $0.2 \mu \mathrm{ml} / \mathrm{l}$ of Dipterex 500 (Trichlorfon). The kidney tissue collected after 24 hours of exposure showed an enlargement of intercapsular space with glomerular atrophy, hypertrophy of the kidney tube cells, with small granules on its cytoplasm and little nuclear alteration. Blood overflowing from capillaries with pyknotic nuclei and vacuoles in the cytoplasm it was also noticed. After 48 hours, the kidney tissue showed glomerular expansion, impossibility to visualize the intercapsular space as well as cytoplasm limit of many cells. The parietal capsular epithelium and the basal membrane presented loss of cell content, the tubular cells appeared swollen vacuolated and with thin and thick cytoplasmatic granulations. Some of the cell nuclei kept relatively regular form with a condensed chromatin on its central region, while others showed themselves relatively small and pyknotics advancing to a cariolisis and necrosis focus.
\end{abstract}

Key words: Kidney, Prochilodus lineatus, “curimbatá”, Trichlorfon

\section{INTRODUCTION}

The agrotoxic use has improved the human life quality in many ways by increasing the agricultural production, improving the food quality and farming products, minimizing losses during transportation and stocking and reducing the disease incidence and making an effective pest control. However the indiscriminate use is responsible for many adverse effects on plants and animals. Agrotoxic products have also been used in fish culture, especially in the ectoparasite treatment because they cause high delay in the fish growth and induced a rate of death. Many times the recommended therapy in the parasite infestation combat is based on chemical products use, especially the organo-phosphates (Rao \& Dad, 1979). However, it is known that the organophosphate used for the disease treatments can also cause histopathologic changes in many

\footnotetext{
${ }^{*}$ Author for correspondence
} 
fish organs but studies in this area are still in an incipient phase (Ram et al., 1989; Hamm et al., 1998; Beaman et al., 1999).

The aim of this bioassay was to investigate the histopathologic changes on the kidney of Prochilodus lineatus exposed to a high Dipterex 500 (Trichlorfon) concentration.

\section{MATERIALS AND METHODS}

Prochilodus scrofa was obtained from fish raising tanks and acclimatized for two weeks in an cement aquarium coated with non toxic synthetic rubber (81 liters), filled with water, continually aerated and cleaned. The temperature was higher than $25^{\circ}$ $\mathrm{C}$ and $\mathrm{pH}$ was $7 \pm 0.2$.

Sixty juveniles specimen (average size $-8.4 \mathrm{~cm}$, weight $-12.3 \mathrm{~g}$ ) were divided in two groups of 30 each. One was the control and other was the contaminated group. The second group was exposed to the water contamination of $0.2 \mu \mathrm{L} / \mathrm{L}$ of Dipterex 500 (Trichlorfon) solution diluted in water. After 24 and 48 hours, five individuals of both groups were anesthetized with benzocaine and sacrificed by medullar section. Fragments of the kidney were fixed in Bouin for a period of 24 hours and after that they were put on wax and stained by Haematoxylin-Eosin staining (Bancroft \& Stevens, 1977).

\section{RESULTS AND DISCUSSION}

Behavior changes of the contaminated fish group were observed after 24 hour exposition to the contaminated water, consisted of agitation, lost of balance with a slow lateral swimming, loss of coordination in recovering normal position, spasmodic movements on peitoral fins, superficial breath with a high opercular amplitude and discontinuous movement on dislocation attempt. According to Dalzell \& McFarland (1999), this behavior was a typical fish intoxication's symptoms, and some of these could summarize in gasping, coughing and lightened respiratory rate, a lack of response to stimuli and loss of equilibrium. The organo-phosphates inhibited the acetylcholinesterase, affecting a colinergic transmission of the central nerve system (CNS) provoking behavior changes (Corbett, 1974).
Fig. 1 shows the control kidney tissue of $P$. lineatus with normal cells and glomerulus. The kidney tissue collected after 24 hours of exposure (Fig. 2) showed an enlargement of intercapsular space with glomerular atrophy, hypertrophy of the kidney tube cells with small granules on its cytoplasm and little nuclear alteration. Blood overflowing from capillaries which in many cases did not permit to see the vessel limit was also noticed. Some areas exhibited necrosis with pyknotic nuclei and vacuoles in the cytoplasm.

After forty-eight hours, the kidney tissue (Fig. 3) showed glomerular expansion rendering impossibility to visualize the intercapsular space as well as cytoplasm limit of many cells. The parietal capsular epithelium and the basal membrane presented loss of cell content, the tubular cells appeared swollen vacuolated and with thin and thick cytoplasmatic granulations. Some of the cell nucleus kept relatively regular form with a condensed chromatin on its central region, while others showed themselves relatively small and pyknotics advancing to a cariolisis forming necrosis focus.

The organophosphates use has been reflected it in other tissues such as blood tissue, causing decrease of the hematological and leukocyte percentage values (Ranzani-Paiva et al., 1997); on gills, provoking hypertrophy and hyperplasy of epithelium cells and structure destruction of the lamellas (Capinpin, 1995). On the hepatic tissue, the organophosphates caused morphologic changes too (Rodrigues \& Fanta, 1998).

It is known that the renal tissue suffers high structure variation when exposed to specific situations on reorganization attempt. For example, a glomerulus size decrease by water salinity changes (Hwang \& Wu, 1998), and necrosis on kidney epithelium cells during the spawning season period (Bucher \& Hofer,1993). As an important organ on the immunity response elaboration (Zapata \& Cooper 1990), morphologic kidney changes may induce defense system changes harming the animal's homeostasis and healthy.

As food source, fish interferes on man's life quality and so more detailed analysis of the action of what may sub lethal doses of pesticide and insecticide substances provoke in these organisms is necessary. 


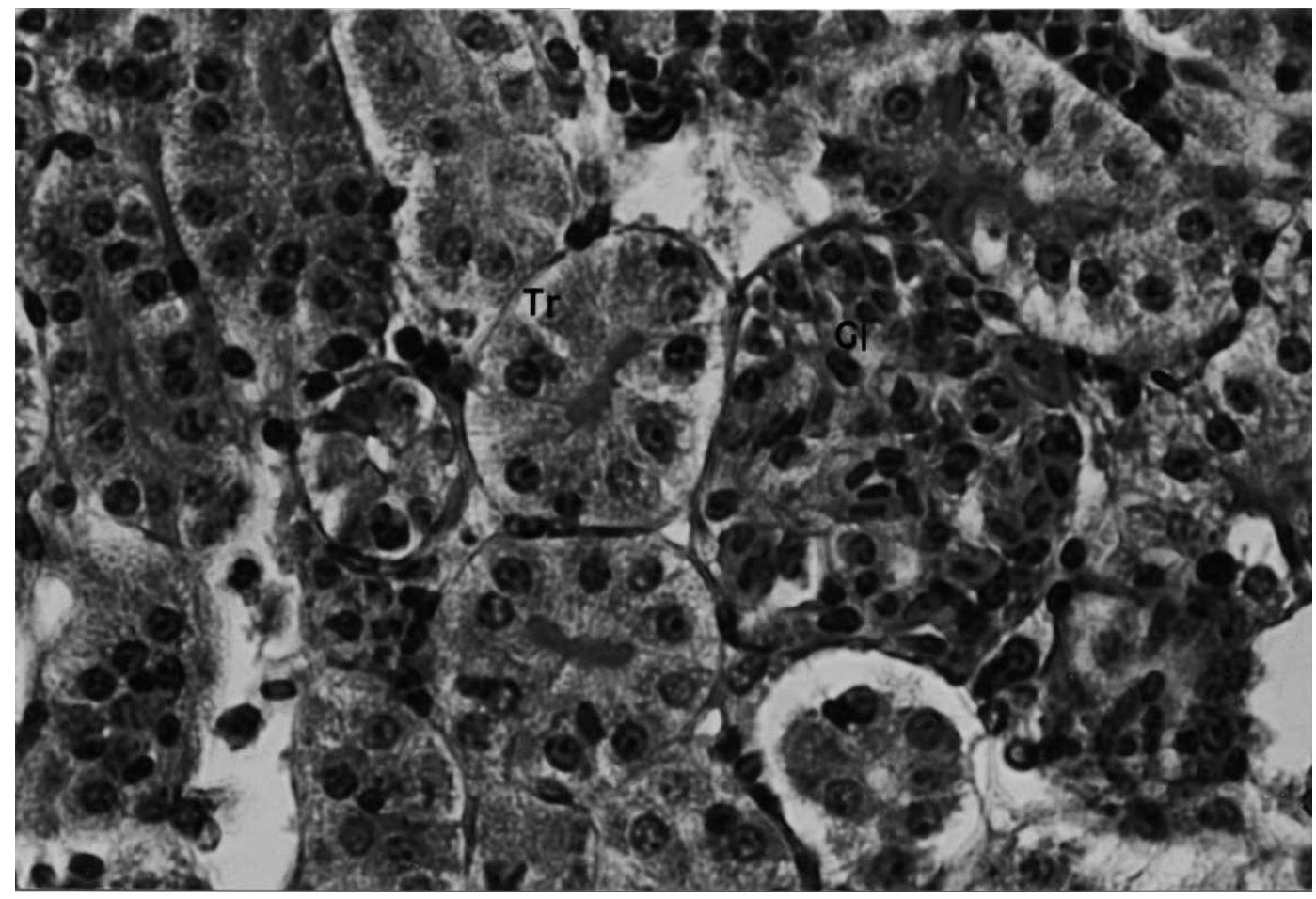

Figure 1 - Control kidney tissue of Prochilodus lineatus showing glomerulus (Gl) and tubules (Tr). HE' 400x.

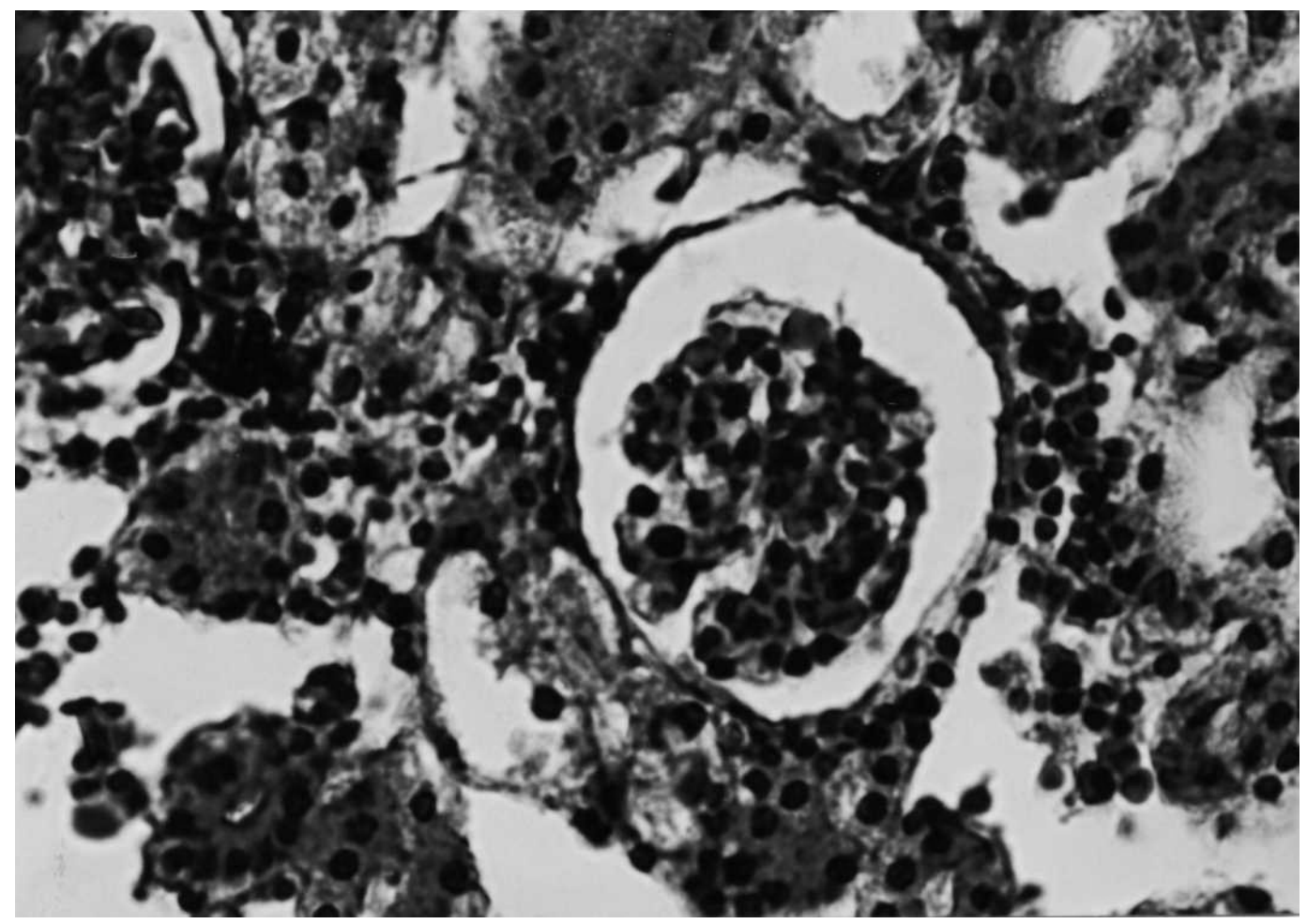

Figure 2 - Kidney tissue of Prochilodus lineatus after 24 hours exposition of Trichlorfon. HE 400x. 


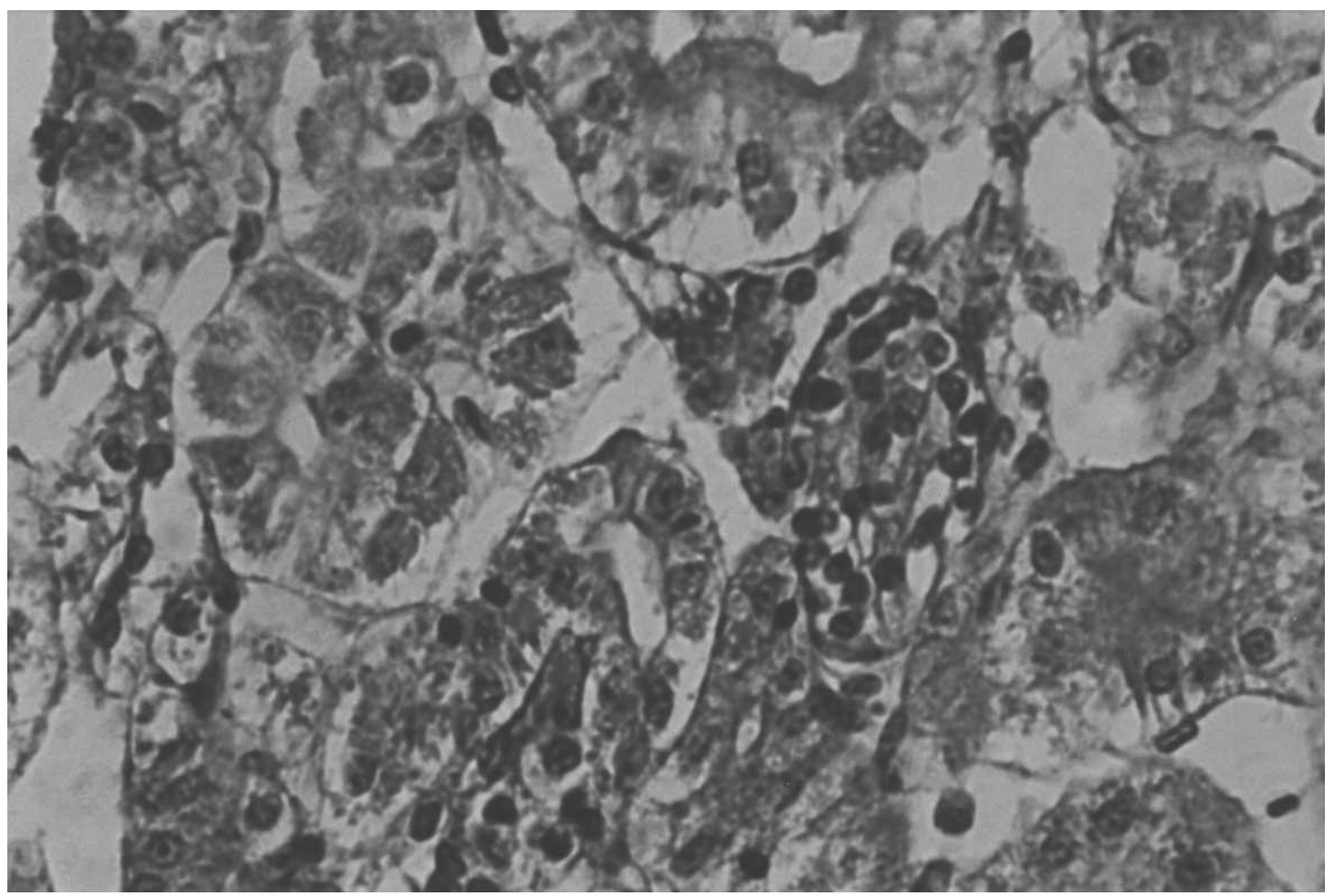

Figure 3 - Kidney tissue of Prochilodus lineatus after 48 hours exposition of Trichlorfon. HE 400x.

\section{RESUMO}

Neste trabalho foram avaliadas as alterações histopatológicas no tecido renal de curimbatá Prochilodus lineatus, através de bioensaio agudo provocado pela contaminação da água por $0,2 \mu \mathrm{l} /$ litro de solução de Dipterex 500 (Trichlorfon) diluído em solução aquosa. Alterações comportamentais dos peixes pertencentes ao grupo contaminado, foram observadas a partir de 24 horas após o início da exposição. $\mathrm{O}$ tecido renal coletado após 24 horas de exposição apresentou aumento do espaço intercapsular com glomérulos atróficos, hipertrofia das células dos túbulos renais, extravasamento sangüíneo a partir de capilares e áreas de necrose. Após 48 horas o tecido renal apresentou dilatação glomerular, perda do conteúdo celular do epitélio capsular parietal e da membrana basal, inchaço, vacuolização e granulações finas e grossas no citoplasma das células tubulares e focos de necrose acentuada.

\section{REFERENCES}

Bancroft, J. D. and Stevens, A. (1977), Theory and practice of histological techniques. Churchill Livingstone.

Beaman, J. R.; Finch, R.; Gardner, H.; Hoffmann, F.; Rosencrance, A. and Zelikoff, J. T. (1999), Mammalian immunoassays for predicting the toxicity of malathion in a laboratory fish model. $J$. Toxicol. Environ. Health, 56 : (8), 523-542.

Bucher, F. and Hofer, R. (1993), Histological and enzyme histochemical changes in the kidney of male bullhead (Cotus gobio) during the spawning period. J. Fish Biol., 42, 403-409.

Capinpin, E. C. (1995), Gill lesions in Nile Tilapia associated with acute malathion poisoning. SEAFDEC Asian Aquaculture, 17 : (3), 4-6.

Corbett, J. R (1974), The biochemical mode of action of pesticides. Academic Press, New York.

Dalzell, D. J. B. and McFarland, N. A. A. (1999), The toxicity of iron to brown trout and effects on the gills: a comparison of two grades of iron sulphate. $J$. Fish Biol., 55, 301-315.

Hamm, J. T.; Wilson, B. W. and Hinton, D. E. (1998), Organophosphate-induced acetylcholinesterase inhibition and embryonic retinal cell necrosis in vivo in the teleost (Oryzias latipes). Neurotoxicology, 19 : (6), 853-869. 
Hwang, P. P. and Wu, S. M. (1988), Salinity effects on cytometrical parameters of the kidney in theeuryhaline teleost Oreochromis mossambicus Peters. J. Fish. Biol., 33, 89-95.

Ram, R. N.; Joy, K. P. and Sathyanesan, A. G. (1989), Cythion-induced histophysiological changes in thyroid and thyrotrophs of the teleost fish, Channa punctatus (Bloch). Ecotoxicol. Environ. Saf., 17 : (3), 272-278.

Ranzani-Paiva, M. J. T.; Rodrigues, E. L.; Eiras, A. C.; Veiga, M. L. and Pacheco, F. J. (1997), Alterações hematológicas em curimbatá, Prochilodus scrofa Steindachner, 1881, exposto ao Dipterex 500 (Trichlorfon). B. Inst. Pesca, 24 (especial), 187-196.
Rao, K. S. and Dad, N. K. (1979), Studies of herbicide toxicity in some freshwater fishes and ectoprocta. $J$. Fish Biol., 14, 517-522.

Rodrigues, E. L. and Fanta, E. (1998), Liver histopathology of the fish Brachydanio rerio Hamilton-Buchanan after exposure to sublethal levels of the organophosphate dimethoate 500. Rev. bras. Zool., 15 : (2), 441-450.

Zapata, A. G. and Cooper, E. L. (1990), The immune system: comparative histophysiology. John Wiley, Chichester. 


\title{
PÁGINA
}

\author{
EM
}

BRANCO 